\title{
Extensive geographic and ontogenetic variation characterizes the trophic ecology of a temperate reef fish on southern California (USA) rocky reefs
}

\author{
Scott L. Hamilton ${ }^{1,2, *}$, Jennifer E. Caselle ${ }^{1}$, Coulson A. Lantz ${ }^{1}$, Tiana L. Egloff ${ }^{1}$, \\ Emi Kondo ${ }^{1}$, Seth D. Newsome ${ }^{3}$, Kerri Loke-Smith ${ }^{4}$, Daniel J. Pondella II $^{5}$, \\ Kelly A. Young ${ }^{4}$, Christopher G. Lowe ${ }^{4}$
}

\author{
${ }^{1}$ Marine Science Institute, University of California Santa Barbara, California 93106-6150, USA \\ ${ }^{2}$ Moss Landing Marine Laboratories, 8272 Moss Landing Rd, Moss Landing, California 95039, USA \\ ${ }^{3}$ Department of Zoology and Physiology, University of Wyoming, 1000 E. University Ave, Dept 3166, Laramie, \\ Wyoming 82071, USA \\ ${ }^{4}$ Deptartment of Biological Sciences, California State University Long Beach, 1250 Bellflower Blvd, Long Beach, \\ California 90840, USA
}

${ }^{5}$ Department of Biology, Moore Laboratory of Zoology, Occidental College, 1600 Campus Rd, Los Angeles, California 90041, USA

\begin{abstract}
Interactions between predator and prey act to shape the structure of ecological communities, and these interactions can differ across space. California sheephead Semicossyphus pulcher are common predators of benthic invertebrates in kelp beds and rocky reefs in southern California, USA. Through gut content and stable isotope $\left(\delta^{13} \mathrm{C}\right.$ and $\left.\delta^{15} \mathrm{~N}\right)$ analyses, we investigated geographic and ontogenetic variation in trophic ecology across 9 populations located at island and mainland sites throughout southern California. We found extensive geographic variation in California sheephead diet composition over small spatial scales. Populations differed in the proportion of sessile filter/suspension feeders or mobile invertebrates in the diet. Spatial variation in diet was highly correlated with other life history and demographic traits (e.g. growth, survivorship, reproductive condition, and energy storage), in addition to proxies of prey availability from community surveys. Multivariate descriptions of the diet from gut contents roughly agreed with the spatial groupings of sites based on stable isotope analysis of both California sheephead and their prey. Ontogenetic changes in diet occurred consistently across populations, despite spatial differences in size structure. As California sheephead increase in size, diets shift from small filter feeders, like bivalves, to larger mobile invertebrates, such as sea urchins. Our results indicate that locations with large California sheephead present, such as many marine reserves, may experience increased predation pressure on sea urchins, which could ultimately affect kelp persistence.
\end{abstract}

KEY WORDS: California sheephead · Channel Islands · Demographic consequences · Feeding habit · Gut contents $\cdot$ Semicossyphus pulcher $\cdot$ Spatial variability $\cdot$ Stable isotopes

\section{INTRODUCTION}

Predator-prey interactions can play a fundamental role in shaping ecological communities (Paine 1969), and variation in the strength of those interactions may affect the structure of assemblages and the functioning of ecosystems (Power 1992). Understanding the ecological and environmental factors responsible for influencing variation in trophic ecology may help to explain species distribution and abundance patterns and the dynamics of communities (Werner \& Mittelbach 1981, Menge et al. 1994). For generalist predators with flexi- 
ble diet preferences, spatiotemporal variability in diet may be a common response to geographic or seasonal variations in prey availability or quality (Foy \& Norcross 1999, McCormick 2003) or inter-individual differences in the prey preferences of the predator (Estes et al. 2003, Tinker et al. 2008). Geographic variation in predator-prey interactions may arise due to local adaptations that allow predators to circumvent prey defenses in one location but not another (Sanford \& Worth 2009). In addition, competition amongst multiple predators for shared prey has been shown to induce prey switching in field experiments (Siddon \& Witman 2004). Spatial and temporal variation in trophic ecology may have important effects on predator populations as well. Differences in diets have been shown to have direct consequences for growth, condition, reproductive success, and survival among geographically distinct populations (Wainright et al. 1996, Foy \& Norcross 1999, McCormick 2003).

In the kelp forests of southern California (USA), California sheephead Semicossyphus pulcher are common generalist predators that prey on a variety of benthic invertebrate taxa, including crustaceans, echinoderms, mollusks, polychaetes, and bryozoans (Cowen 1983, 1986). Previous work has indicated extensive variation in California sheephead diets over large geographic scales, between 1 site in southern California and 3 sites in central Baja California, Mexico (Cowen 1986). Sitespecific diet differences appeared to be explained by differences in prey availability, which may exhibit feedbacks with California sheephead densities and be influenced by productivity (Cowen 1986). In addition, studies have estimated the predatory impacts of California sheephead on populations of red sea urchins (Cowen 1983) and brachyuran crabs (Cowen 1986). These studies demonstrated that California sheephead can play an important role in regulating prey abundance and behavior.

Previous work has also demonstrated extensive geographic variation in the demography and life histories of California sheephead throughout its range. Populations differ in terms of growth rates, size structure, natural mortality, and the timing of maturation and sex change, with variation linked to temperature, local densities of conspecifics, and the effects of fishing (Warner 1975, Cowen 1990, Hamilton et al. 2007, Caselle et al. 2011). However, geographic variation in trophic ecology may also directly influence demographic variation among populations, as differences in prey abundance or quality can influence growth and energy storage, and indirectly affect related life history traits, survivorship, and reproduction (Wainright et al. 1996, Sutton \& Ney 2001, McCormick 2003). Examining links between diet and demography may aid in efforts to better understand ecosystem dynamics.
Diets may also change throughout ontogeny as species switch to different prey types as they grow larger in size. For example, many piscivorous fish eat invertebrates as juveniles and switch to piscivory during ontogeny; the timing of the switch can have important demographic consequences (Olson 1996, Buckel et al. 1998). In addition, predatory fish on the US east coast have been shown to expand their diet breadth with increasing body size relative to their prey (Scharf et al. 2000). Ontogenetic variation can have important consequences for ecosystem structure and function. For example, Ling et al. (2009) recently demonstrated in Tasmania that only large lobsters are capable of preying upon an invasive species of sea urchin that is currently expanding its range due to global climate change. They reported that kelp beds inside marine reserves, where large predator lobsters were present, showed increased resilience against the barrens-forming sea urchin relative to fished sites outside of reserves where sea urchin survival was higher and thus the risk of phase shift to urchin barrens was also higher. Studies have not previously investigated ontogenetic variation in the trophic ecology of California sheephead; however, given their position as top predators of sea urchins, ontogenetic shifts in diet may have important consequences for the structure and function of southern California's kelp forests (Tegner \& Dayton 1981, 2000, Harrold \& Reed 1985, Graham 2004). In addition, an improved understanding of how species interactions change as a function of prey and predator size may aid resource management efforts.

We examined geographic variation in trophic ecology of California sheephead from 9 distinct populations at island and mainland locations throughout southern California, by combining detailed studies of gut contents with stable isotope analysis of both predator and prey. Given previous findings of differences in diet near the ends of the range of California sheephead (Cowen 1986), we examined variation at smaller spatial scales among populations within southern California. We then related geographic variation in diet to population level demography, and to the abundance of California sheephead, various prey taxa, and habitat characteristics recorded on visual surveys. Finally, we examined ontogenetic variation in trophic ecology and assessed whether size-specific diet differences varied consistently across our 9 sampling locations.

\section{MATERIALS AND METHODS}

Study species. California sheephead are large temperate wrasses (family Labridae) which inhabit nearshore rocky reefs and kelp beds from central California throughout Baja California, Mexico, including the Gulf 
of California. Home ranges are relatively small (0.3 to $1.2 \mathrm{~km}$ alongshore), and individuals appear to show site fidelity (Topping et al. 2006). Recruitment of sheephead is generally consistent from year to year in the southern and central part of its range, but becomes more episodic to the north, reportedly corresponding with El Niño flow-reversals (Cowen 1985). California sheephead are protogynous hermaphrodites and are capable of changing sex from female to male through a documented series of gonadal changes as well as morphological color changes (Warner 1975, Sundberg et al. 2009). Commercial and recreational fisheries exist for this species throughout its range (Mexico: RosalesCasian \& Gonzalez-Camaho 2003; USA: Alonzo et al. 2004), and commercial landings increased dramatically in southern California in the 1990s with the advent of a trap fishery for live-caught fish (Alonzo et al. 2004).

Study sites and collections. To examine geographic and ontogenetic variation in the trophic ecology of California sheephead, we collected individuals from 9 locations ( $\mathrm{n}=44$ to 76 per location) in southern California, including 7 in the Channel Islands and 2 along the mainland coast (Fig. 1), during June to September of 2007 and 2008. In general, sheephead are more abundant at the offshore islands than along the mainland coast (Caselle et al. 2011). At the island locations,

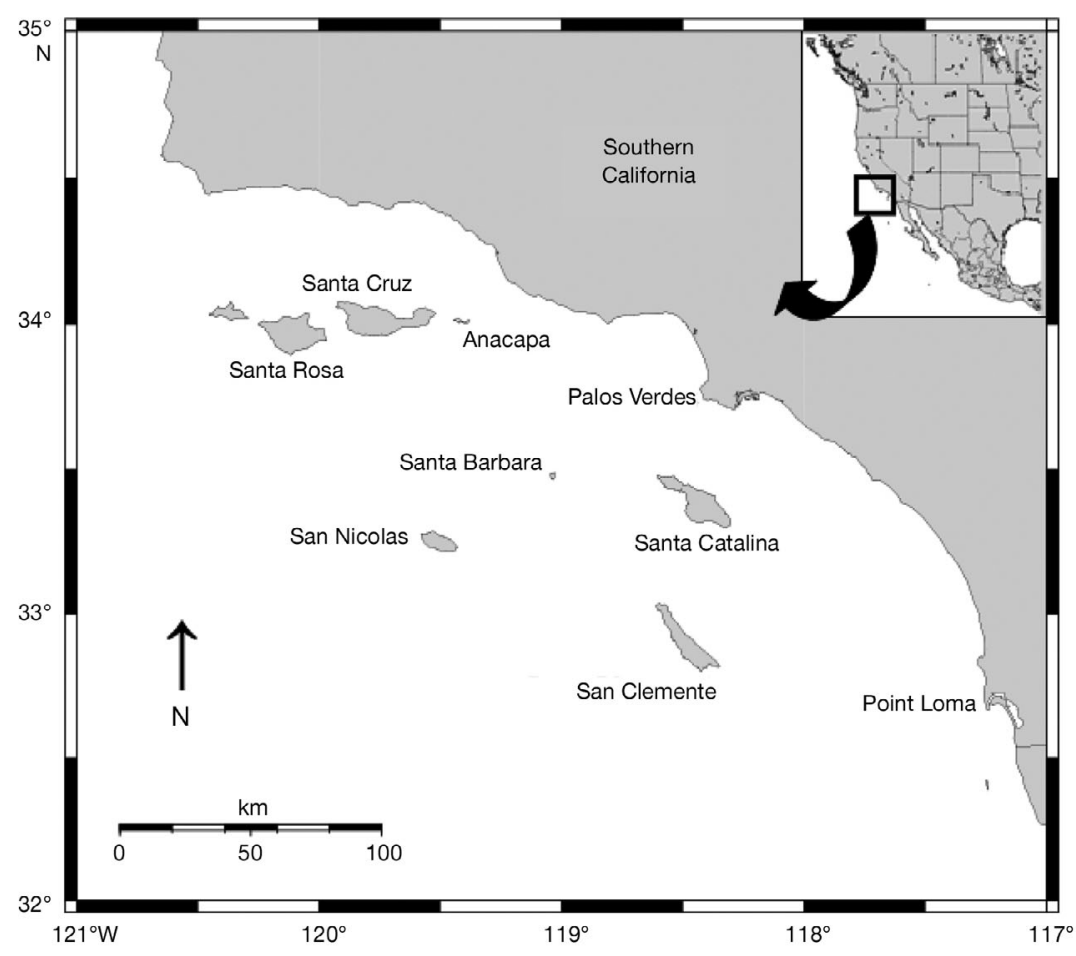

Fig. 1. Study region, showing the 9 collection locations of California sheephead throughout southern California. Sites include 7 of the offshore Channel Islands and 2 sites along the mainland coast collections were typically spread across multiple dive sites separated by 5 to $10 \mathrm{~km}$, while at the 2 mainland locations, collections were restricted to 1 (Point Loma) or 2 (Palos Verdes) dive sites. All collections occurred at depths of 8 to $18 \mathrm{~m}$. Collections were made primarily with SCUBA using spears, but we also employed hook and line and trap gear on occasion. While spearing, we attempted to catch representative samples of the size structure present at each site by collecting the first individual encountered, regardless of size, before moving on to catch the next encountered individual. Collected fish were stored on ice and dissected within $8 \mathrm{~h}$ of capture. For each individual, we measured total, standard, and fork length, body depth, and gape in $\mathrm{mm}$, weighed each individual to the nearest $10 \mathrm{~g}$, and determined sex by visual inspection of the gonads, and later confirmed this by histological preparations. We dissected and weighed the gonads, liver, and stomach to the nearest $1 \mathrm{~g}$ and stored the stomach contents in $10 \%$ buffered formalin (for $1 \mathrm{wk}$ prior to moving to $95 \%$ ethanol for permanent storage). We also measured the volume of the gut contents in ml. For stable isotope analysis, we removed a small section of the dorsal musculature above the pectoral fin and stored it on liquid nitrogen (before transferring to a $-80^{\circ} \mathrm{C}$ freezer). Finally, the first and second dorsal spines were removed and frozen for later age-based analysis of annual rings (see Hamilton et al. 2007 for aging methods).

We conducted visual community surveys at each location during July to Sept 2008 to measure the abundance of algae, invertebrates, and fish, and to characterize habitat in participation with the PISCO and Bight '08 programs. At each site, divers established 24 fish transects that were $30 \times 2 \times 2 \mathrm{~m}$ at 3 levels in the water column: benthic, midwater, and canopy/surface. Transects were laid out in a stratified random design, with multiple non-permanent transects located in fixed strata (i.e. outer, middle, and inner edges of the reef). At each level in the water column, 1 diver per transect counted and sized all fish to the nearest $\mathrm{cm}$ (total length). In addition, divers established 12 benthic transects at each site to characterize community structure of invertebrates (i.e. potential California sheephead prey) and macroalgae (i.e. habitat structure for fish and various invertebrate prey taxa) along $30 \times 2 \mathrm{~m}$ swaths and substrate occupancy, substrate type, and physical relief using uniform point contact methods at 30 points 
along each transect line. Unfortunately, these surveys were not designed to accurately measure the abundances of small cryptic invertebrates (e.g. gastropods, bivalves, crabs), which comprise the bulk of the prey items consumed by California sheephead. However, the abundance of larger conspicuous species or the percent cover of major functional groups may serve as a proxy for cryptic taxa. Transects were conducted with SCUBA in depths shallower than $20 \mathrm{~m}$ at each site. For each island or mainland location where California sheephead collections occurred, we used the average density or percent cover from 2 to 6 nearby sites (i.e. within $10 \mathrm{~km}$ of a collection location) as metrics to examine differences in California sheephead density, prey availability, or habitat structure.

Gut content and stable isotope analyses. To assess the proportional contribution of different prey items to the diet of individual California sheephead, we sorted through the gut contents and visually estimated the percent of each sample represented by 26 prey classes that were identified previously by Cowen (1986). The entire gut sample was spread into a large glass dish, and 2 observers used a dissecting microscope to sort the contents into different prey taxa categories. The proportional contribution of each prey taxon as a function of the total gut volume was then recorded. Gut contents provide a snapshot of the feeding habits of an individual at a single point in time and may not be fully representative of the diet of generalist predators that may switch prey sources from day to day. Therefore, we also performed stable isotope analysis $\left(\delta^{13} \mathrm{C}\right.$ and $\delta^{15} \mathrm{~N}$ ) to provide a more integrated picture of diet. Stable isotopes in dorsal muscle tissue of fishes have been shown to integrate feeding conditions on a scale of months to years, due to tissue turnover times (Hesslein et al. 1993). We also collected tissue samples of common prey items of California sheephead $(\mathrm{n} \approx 20$ per prey taxon) and samples of benthic (e.g. giant kelp Macrocystis pyrifera) and pelagic (e.g. phytoplankton from particulate organic matter, $\mathrm{POM}$ ) primary producers at 2 different sites on the north shore of Santa Cruz Island (Pelican Bay and Coche Point). Prey items included bryozoans Membranipora spp., barnacles Megabalanus spp., small brachyuran crabs (Scyra acutifrons, Pugettia richii, and Cancer spp.), brittle stars Ophiothrix spp., gastropods Tegula spp., purple sea urchins Strongylocentrotus purpuratus, red sea urchins S. franciscanus, and scallops Crassadoma giganteum.

Samples of California sheephead dorsal muscle tissue were rinsed in dilute $\mathrm{HCl}$, freeze-dried for $72 \mathrm{~h}$, and then ground into a fine powder using a mortar and pestle. Lipids were not extracted from prey item samples prior to analysis. For prey items, we removed soft muscle tissue (barnacles, crabs, gastropods, mussels, scallops, sea urchins) or used whole organisms (brittle stars and bryozoans) and the same preparation steps described previously. Water samples were collected $1 \mathrm{~m}$ above the bottom at depths of 8 to $12 \mathrm{~m}$ in 201 jugs. POM samples were removed by filtering and retaining the $<150 \mu \mathrm{m}$ size fraction on glass fiber filters for later stable isotope analysis. Samples were run on a Finnigan Delta Plus Advantage mass spectrometer in the Analytical Lab at the Marine Science Institute at UCSB for stable isotopes of carbon and nitrogen. Samples were compared to standards for atmospheric nitrogen (for ${ }^{15} \mathrm{~N}$ ) and Vienna Peedee belemnite limestone (for $\left.{ }^{13} \mathrm{C}\right)$. Stable isotope ratios of carbon $\left(\delta^{13} \mathrm{C}_{i}\right.$ proxy for carbon source) and nitrogen $\left(\delta^{15} \mathrm{~N}_{i}\right.$ proxy for trophic level) were expressed in parts per thousand (\%o). Primary production in coastal marine ecosystems is dominated by phytoplankton $\left(\delta^{13} \mathrm{C}\right.$ values around $-20 \%$ ) and macroalgae such as kelp $\left(\delta^{13} \mathrm{C}\right.$ values around $-14 \%$ ) (Page et al. 2008). Trophic discrimination occurs and ${ }^{15} \mathrm{~N}$ is enriched relative to ${ }^{14} \mathrm{~N}$ in higher trophic levels, and $\delta^{15} \mathrm{~N}$ increases on average by 3 to $5 \%$ for each 1-step increase up the food chain (Minagawa \& Wada 1984, Kelly 2000, Post 2002). Trophic discrimination also occurs for carbon and $\delta^{13} \mathrm{C}$ increases by 0 to $2 \%$ per trophic level (Kelly 2000, Post 2002).

Data analysis. To examine geographic variation in trophic ecology among populations, we used principal components analysis (PCA) on the 13 most common gut items ( $>1 \%$ by volume averaged across all fish) to examine similarities and differences in diet composition. The first principal component (PC1) explained $15 \%$ of the variation while PC2 explained $12 \%$. This low level of explained variation is likely due to the highly variable nature of gut contents, which provide a snapshot of trophic interactions on a given day, often resulting in a preponderance of zeros in the dataset within a site, even for common gut items. Using the average scores of the first 2 PCs for each population, we conducted correlation analyses to ascertain whether particular demographic and life history variables helped to explain spatial variation in California sheephead diets. We also examined correlations between the PC scores from gut contents and the $\delta^{13} \mathrm{C}$ and $\delta^{15} \mathrm{~N}$ stable isotope ratios.

To assess the influence of feeding ecology on life history traits, we calculated the gonadosomatic index of mature females (GSI: \% gonad weight relative to body weight) as a proxy for reproductive condition because all individuals were collected during the breeding season, which occurs from May to September (Warner 1975). We also calculated the hepatosomatic index of all individuals (HSI: \% liver weight relative to body weight) as a proxy for condition because fish often use the liver as an energy storage organ (Lambert \& Dutil 1997), and HSI may be influenced by diet variation. We used age-based catch 
curves to estimate annual mortality rates $(Z)$ following standard fisheries methods (e.g. Beverton \& Holt 1957, Robertson et al. 2005). Mortality rates were calculated using log-linear regressions of the agefrequency data $(Z=$ regression slope), excluding fish younger than the peak age mode. Estimates of annual survival rates $(S)$ were then calculated according to the equation $S=\mathrm{e}^{-Z}$, following Ricker (1975). We used least squares regression techniques to fit the von Bertalanffy growth equation $L_{t}=L_{\text {inf }}\left(1-\mathrm{e}^{K\left(t-t_{0}\right)}\right)$ to the size-at-age $\left(L_{\mathrm{t}}\right)$ data, using standard length (SL, $\mathrm{mm}$ ) and age (yr) from preparations of polished thin sections of dorsal spines. From the von Bertalanffy fits to each population, we extracted values for 2 parameters, $L_{\text {inf }}$ a proxy for maximum size of individuals in a population, and $K$, a proxy of the rate of approach to that predicted maximum size. Logistic regression was used to calculate the timing of maturation and sex change in each population, as a function of the proportion of different size classes in various sexual states (i.e. immature, female, or male).

We used analysis of variance (ANOVA) to examine spatial variation in biological and habitat variables across the 9 study locations and used step-wise multiple regression to investigate relationships between diet composition and a suite of predictor variables from community surveys. We assessed ontogenetic variation in trophic ecology by testing for changes in diet composition and stable isotope ratios with California sheephead size. Across locations, individuals were grouped into $50 \mathrm{~mm}$ SL size classes. We then calculated the average stable isotope ratios and the average proportion of common prey items in the gut contents for each size class at each site. Averaging diet information across sites for each size class, we used linear regression to test for significant relationships between size and diet. We also used analysis of covariance (ANCOVA) on the site-level average diet information to examine relationships within and among populations across size classes, using the factors of size class, location, and their interaction.

\section{RESULTS}

\section{Geographic variation in trophic ecology}

California sheephead are generalist predators on a variety of kelp forest invertebrates (Fig. 2a). Out of 26 identified prey categories, 13 gut items occurred at $>1 \%$ by volume across the 9 sampling locations, so we focused further analyses on these prey types. Within southern California, we found extensive geographic differences in diets (Fig. 2a). While most populations consumed similar prey types, the proportional contri- bution of each prey type to the diet of California sheephead differed greatly among locations. Geographic differences in diets were well described by the loadings of PCs in multivariate space (Fig. 2b). Populations on Santa Rosa, Santa Cruz, and San Nicolas Islands had diets dominated by prey items such as brachyuran crabs, isopods, and gammarid amphipods, while those on Anacapa Island, Santa Barbara Island, and Palos Verdes showed a greater emphasis on consuming sea urchins, bivalves (small clams and mussels), and brittle stars. In contrast, populations on Santa Catalina and San Clemente Islands preyed on barnacles, gastropods, bryozoans, and algae. California sheephead at Point Loma consumed relatively equal amounts of the dominant prey items (Fig. 2).

PC1 generally described populations that either prey on mobile invertebrates (negative values = sea urchins, crabs, isopods) or sessile filter feeders and algae (positive values $=$ bryozoans, barnacles, algae). Across the 9 sampled populations, we found significant negative correlations between a variety of demographic and life history variables and PC1 describing gut contents (Table 1, Fig. 3). Populations that had mobile invertebrates such as sea urchins and crabs (i.e. negative PC1 values) in the guts were characterized by having larger maximum size (Fig. 3a), higher annual survivorship (Fig. 3b), larger size at maturation (Fig. 3c), higher GSIs for mature females (Fig. 3d), and higher HSIs (Fig. 3e). Populations with negative PC1 scores also had enriched $\delta^{13} \mathrm{C}$ signatures (Fig. 3f), as would be expected for predators whose prey consume benthic sources of primary production (i.e. kelp) as opposed to pelagic sources (i.e. phytoplankton), which are indicative of filter feeders. One important note is that many of these life history variables are positively correlated with each other, so geographic influences on trophic ecology may only directly affect a subset of these variables. We did not find any significant correlations among populations between PC2 (negative values = urchins and bivalves; positive values = crabs, isopods, and gammarid amphipods) and various demographic and life history variables (Table 1).

Stable isotope biplots of average $\delta^{13} \mathrm{C}$ and $\delta^{15} \mathrm{~N}$ signatures from dorsal muscle tissue showed roughly similar geographic groupings among locations (Table 2, Fig. 4a) as the PCA (Fig. 2b). As predicted by the gut content results, California sheephead depleted in ${ }^{13} \mathrm{C}$ (i.e. more negative $\delta^{13} \mathrm{C}$ values), from San Clemente and Santa Catalina Islands tended to have diets composed of sessile filter/suspension feeders that consume phytoplankton at the base of the food chain (Table 2, Fig. 4). In contrast, populations enriched in ${ }^{13} \mathrm{C}$, such as the Northern Channel Islands (Santa Rosa, Santa Cruz, Anacapa), San Nicolas Island, and along the mainland coast, had diets dominated by mobile invertebrates that 


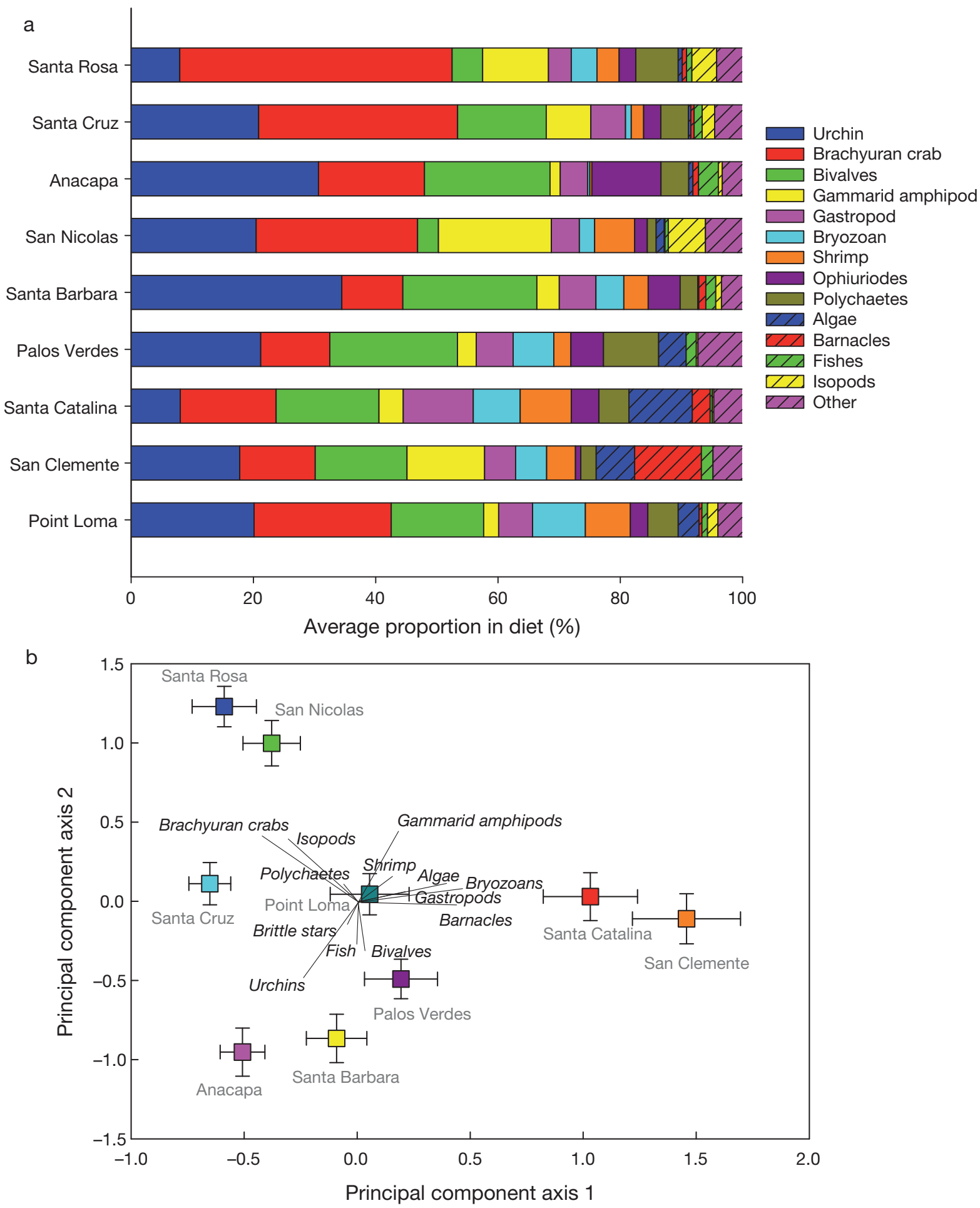

Fig. 2. Semicossyphus pulcher. (a) Spatial variation in California sheephead diets revealed by gut content analysis. Shown are the average proportions of different food items by volume in the guts of California sheephead collected at 9 sampling locations in southern California. Taxa occurring less than $1 \%$ by volume on average across populations were grouped into an 'Other' category. (b) Principal components analysis of the 13 most common gut content categories ( $>1 \%$ by volume on average across the 9 sites) of sheephead from sites throughout southern California. Points indicate the average principal component (PC) scores while error bars are $\pm 1 \mathrm{SE}$. Lines indicate the eigenvector scores for each gut item. PC1 explained $15 \%$ of the variation while PC2 explained $12 \%$ of the variation 
Table 1. Semicossyphus pulcher. Pearson correlations between principal component (PC) scores from gut content analysis and various demographic and life history traits of California sheephead averaged across 9 sampling locations in southern California. Statistically significant correlations are in bold. PC1 is positively correlated with algae, bryozoans, gastropods, and barnacles in the diet and negatively correlated with urchins, brachyuran crabs, and isopods. PC2 is positively correlated with brachyuran crabs, isopods, and gammarid amphipods and negatively correlated with urchins, bivalves, brittle stars, and fish. $L_{\text {inf }}$ : proxy for maximum predicted size; $K$ : proxy for the rate of approach to $L_{\text {inf; }}$ GSI: gonadosomatic index; HSI: hepatosomatic index

\begin{tabular}{|c|c|c|c|c|c|c|c|c|}
\hline & $L_{\mathrm{inf}}$ & $K$ & $\begin{array}{l}\text { Survivor- } \\
\text { ship }\end{array}$ & $\begin{array}{c}\text { Size at } \\
\text { maturation }\end{array}$ & GSI & HSI & $\delta^{13} \mathrm{C}$ & $\delta^{15} \mathrm{~N}$ \\
\hline PC1 & -0.81 & 0.28 & -0.92 & -0.96 & -0.69 & -0.77 & -0.72 & 0.08 \\
\hline PC2 & 0.24 & 0.03 & 0.30 & 0.12 & 0.28 & 0.29 & 0.36 & 0.16 \\
\hline
\end{tabular}

eat kelp and other benthic macroalgae as the source of carbon. Santa Barbara Island is the sole site where gut contents did not predict stable isotope signatures because the gut contents indicated a relatively high importance of sea urchins in the diet while stable isotopes suggested that this population was depleted in ${ }^{13} \mathrm{C}$. However, bivalves were also a large component of the diet at Santa Barbara Island, and this may explain the discrepancy.

Stable isotope values from common prey items collected from sites on
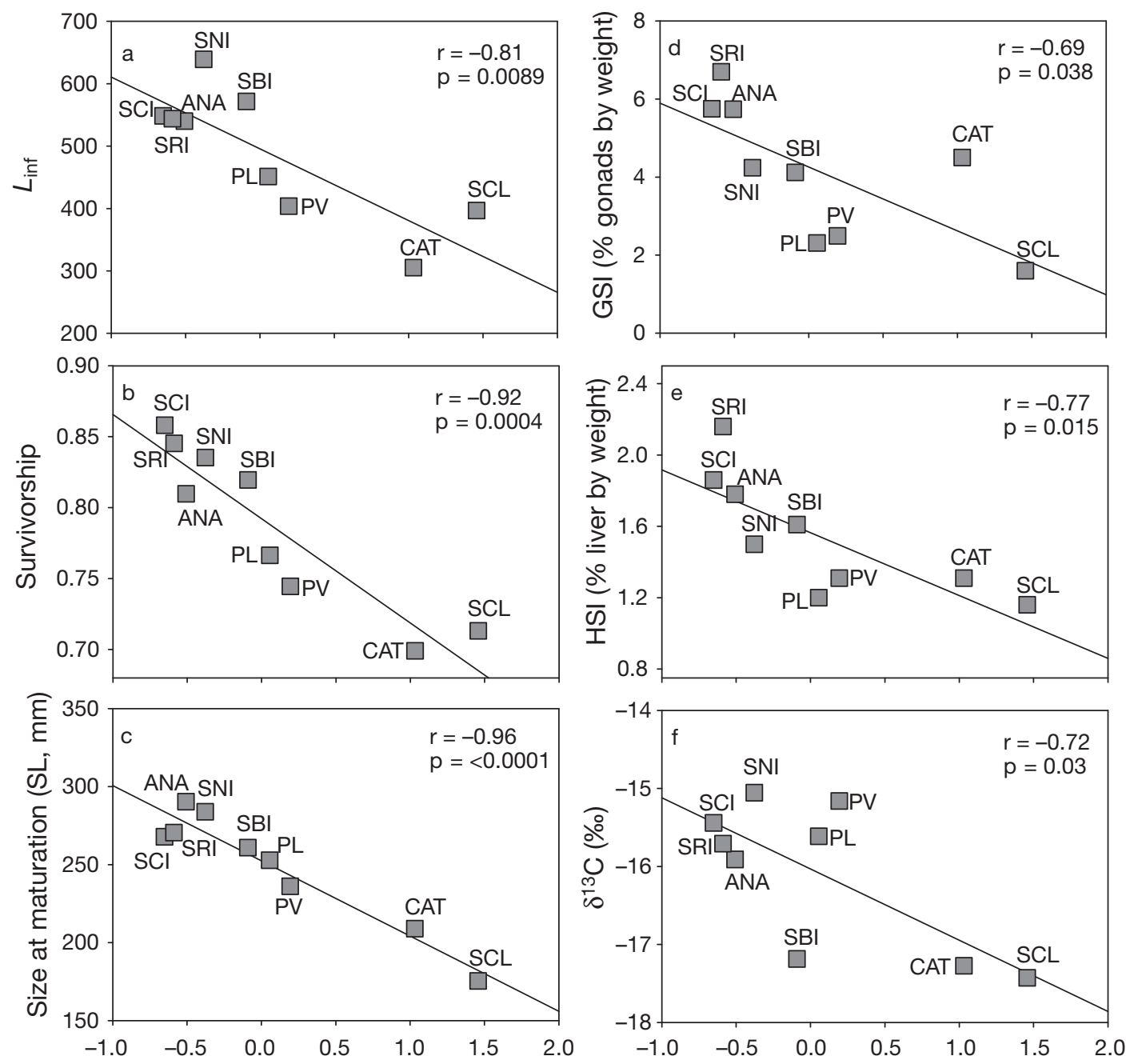

(Crabs, urchins, isopods)

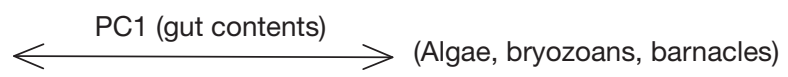

Fig. 3. Semicossyphus pulcher. Correlations between principal component 1 (PC1, measured from gut content analysis) and various life history and demographic parameters that characterize different populations of California sheephead in southern California. (a) $L_{\text {inf }}$ (maximum predicted size), (b) annual survivorship, (c) size at maturation, (d) gonadosomatic index (GSI) of mature females, (e) hepatosomatic index (HSI), (f) $\delta^{13}$ C. Site abbreviations: ANA: Anacapa; CAT: Santa Catalina; PL: Point Loma; PV: Palos Verdes; SCL: San Clemente; SNI: San Nicolas; SBI: Santa Barbara; SCI: Santa Cruz; SRI: Santa Rosa 
Santa Cruz Island (Table 2, Fig. 4b) confirmed the shift in $\delta^{13} \mathrm{C}$ between filter/suspension feeders (e.g. barnacles, bryozoans, mussels, scallops), which are depleted in ${ }^{13} \mathrm{C}$ and reflect the isotopic carbon signature of POM $(-20.1 \pm 1.5 \%$ [ $1 \mathrm{SD}])$, and mobile invertebrates (e.g. brittle stars, crabs, gastropods, sea urchins), which are enriched in ${ }^{13} \mathrm{C}$ and reflect the isotopic carbon signature of giant kelp Macrocystis pyrifera $(-13.5 \pm 2.2 \%$ ). On the $\delta^{13} \mathrm{C}$ axis, California sheephead fall in between giant kelp and POM (Fig. 4b), agreeing with the gut content results of a mixed diet of filter feeders and mobile benthic invertebrates; the relative importance of each prey type varies geographically.

The same prey taxa collected in different locations or at different times may exhibit variable stable isotope signatures that can affect the isotopic signatures measured in higher-order consumers. Because we were only able to collect prey samples from Santa Cruz Island, we addressed the potential for spatial variation in prey isotopes to influence California sheephead isotopic patterns (Fig. 4a) by comparing our data to other studies that examined the isotopic composition of similar prey taxa in southern California (Table 3). The results indicate that most prey taxa and the 2 primary producers showed surprisingly consistent $\delta^{13} \mathrm{C}$ values across studies. Importantly, the variation within taxa across studies is much less than the variation between

Table 2. Semicossyphus pulcher. Sample sizes and means $\pm \mathrm{SD}$ of $\delta^{13} \mathrm{C}, \delta^{15} \mathrm{~N}$, and $\mathrm{C}: \mathrm{N}$ values among 9 California sheephead populations and various prey items collected from kelp beds at Santa Cruz Island. POM: particulate organic matter, nd: no data

\begin{tabular}{|lcccr|}
\hline & $\mathrm{n}$ & \multicolumn{1}{c}{$\delta^{13} \mathrm{C}$} & \multicolumn{1}{c}{$\delta^{15} \mathrm{~N}$} & $\mathrm{C}: \mathrm{N}$ \\
\hline Sheephead populations & & & & \\
Santa Rosa & 44 & $-15.70 \pm 0.72$ & $15.68 \pm 0.32$ & $3.26 \pm 0.21$ \\
Santa Cruz & 76 & $-15.44 \pm 0.56$ & $15.36 \pm 0.43$ & $3.20 \pm 0.10$ \\
Anacapa & 59 & $-15.91 \pm 0.45$ & $15.28 \pm 0.29$ & $3.18 \pm 0.06$ \\
San Nicolas & 71 & $-15.05 \pm 1.01$ & $15.69 \pm 0.49$ & $3.16 \pm 0.12$ \\
Santa Barbara & 56 & $-17.18 \pm 0.59$ & $15.59 \pm 0.46$ & $3.20 \pm 0.06$ \\
Palos Verdes & 46 & $-15.16 \pm 0.43$ & $16.05 \pm 0.29$ & $3.24 \pm 0.11$ \\
Santa Catalina & 44 & $-17.27 \pm 0.65$ & $15.40 \pm 0.62$ & $3.11 \pm 0.04$ \\
San Clemente & 50 & $-17.43 \pm 0.91$ & $15.61 \pm 0.57$ & $3.17 \pm 0.04$ \\
Point Loma & 53 & $-15.61 \pm 0.38$ & $16.07 \pm 0.38$ & $3.29 \pm 0.13$ \\
& & & & \\
Prey items/primary producers & & & \\
Red sea urchin & 21 & $-13.84 \pm 1.11$ & $12.07 \pm 0.89$ & $3.52 \pm 0.27$ \\
Purple sea urchin & 19 & $-12.69 \pm 0.78$ & $11.37 \pm 0.47$ & $3.51 \pm 0.21$ \\
Brittle star & 20 & $-12.79 \pm 0.64$ & $12.06 \pm 0.63$ & $5.10 \pm 0.51$ \\
Gastropod & 20 & $-14.45 \pm 0.71$ & $11.21 \pm 0.32$ & $3.62 \pm 0.10$ \\
Brachyuran crab & 17 & $-15.30 \pm 0.48$ & $10.85 \pm 0.63$ & $4.29 \pm 0.35$ \\
Barnacle & 20 & $-19.85 \pm 0.60$ & $11.77 \pm 0.40$ & $3.90 \pm 0.31$ \\
Mussel & 20 & $-19.00 \pm 1.12$ & $9.53 \pm 0.58$ & $3.23 \pm 0.11$ \\
Rock scallop & 18 & $-16.81 \pm 0.49$ & $10.38 \pm 0.25$ & $3.20 \pm 0.05$ \\
Bryozoan & 25 & $-19.26 \pm 1.63$ & $7.49 \pm 0.36$ & $4.20 \pm 0.48$ \\
Giant kelp & 27 & $-13.48 \pm 2.17$ & $7.27 \pm 0.46$ & $11.60 \pm 0.54$ \\
Phytoplankton (POM) & 27 & $-20.11 \pm 1.48$ & $5.49 \pm 1.08$ & nd \\
\hline
\end{tabular}

filter feeders and benthic consumers within any particular study; filter feeders are consistently depleted in ${ }^{13} \mathrm{C}$ relative to benthic consumers. Based on this evidence and the complementary results of the gut content analysis, we are confident that the spatial variation in isotopic signatures among California sheephead populations is most likely explained by differences in diet composition rather than prey isotope shifts; however, as discussed later, prey isotope shifts may partially explain the relatively low $\delta^{13} \mathrm{C}$ value for Santa Barbara Island.

\section{Geographic variation in biological and habitat covariates in the context of trophic ecology}

California sheephead densities varied significantly (ANOVA, $F_{8,22}=5.19, \mathrm{p}=0.0013$ ) among the 9 study locations, with highest densities at San Clemente, Catalina, and San Nicolas Islands, and lowest densities at Point Loma and a few of the northern Channel Islands (Fig. 5a). Giant kelp Macrocystis pyrifera stipe densities were highest at Catalina and Santa Rosa Islands and lowest at Santa Barbara and San Clemente Islands (ANOVA, $F_{8,21}=4.13, \mathrm{p}=0.0043$; Fig. $5 \mathrm{~b}$ ), while understory macroalgae (i.e. Eisenia arborea, Laminaria spp., Pterygophora californica) showed similar but non-significant patterns (ANOVA, $F_{8,22}=1.57, \mathrm{p}=$ 0.19; Fig. 5d). Sea urchins (Strongylocentrotus franciscanus and S. purpuratus) attained highest densities at Anacapa, Santa Cruz, and Santa Barbara Islands (ANOVA, $F_{8,22}=3.73, \mathrm{p}=$ 0.0067; Fig. 5c), while large crustaceans (i.e. Cancer spp., Panulirus interruptus; ANOVA, $F_{8,22}=1.72, \mathrm{p}=0.14$; Fig. 5e) and mobile mollusks (i.e. Cypraea spadicea, Kelletia kelletii, Megastraea undosa, Megathura crenulata; ANOVA, $F_{8,22}=3.61, p=0.008 ;$ Fig. 5f) were abundant at these locations as well as Santa Catalina Island. Geographic differences existed in the percent cover of substrate types $\left(\chi^{2}=186.4, \mathrm{p}<0.0001\right)$; however, all locations were dominated by bedrock with the exception of relatively higher coverage by boulder habitat on Santa Catalina Island (Fig. 5g). Substrate cover differed across study locations $\left(\chi^{2}=98.7, \mathrm{p}<\right.$ 0.0001 ), with relatively higher cover of sessile invertebrates and abiotic habitat occurring at the northern Channel Islands compared to the southern islands and the mainland (Fig. 5h). 


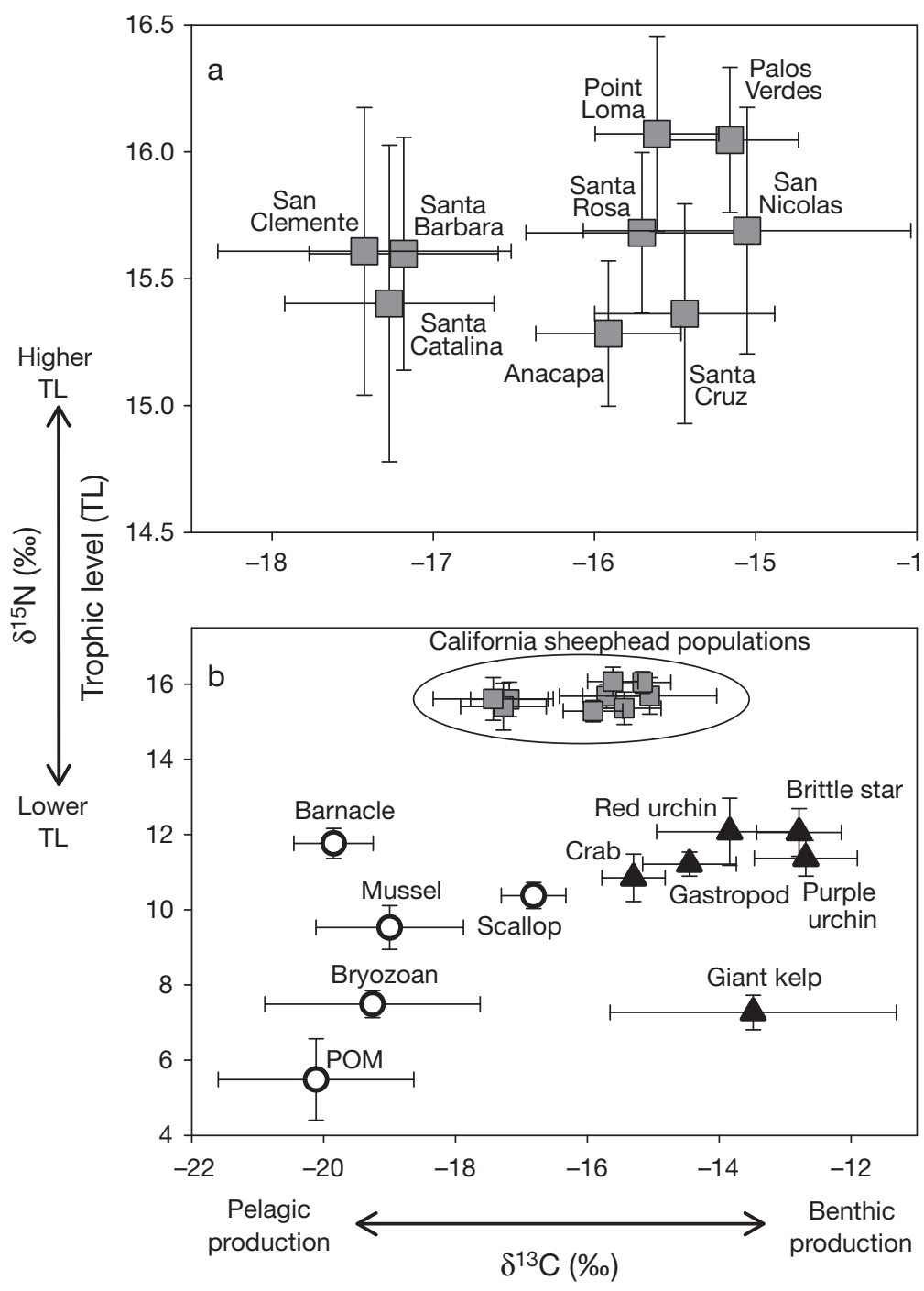

Fig. 4. Semicossyphus pulcher. Spatial variation in trophic ecology of California sheephead identified with stable isotopes. Values are means $\pm 1 \mathrm{SD}$. (a) Average $\delta^{13} \mathrm{C}$ (i.e. proxy of source of primary production) and $\delta^{15} \mathrm{~N}$ (i.e. proxy for trophic level) values for each population. (b) Stable isotope values of California sheephead populations $(\square)$ and various common prey items found in the gut contents, including a number of sessile filter feeders $(O)$ and benthic feeding macroinvertebrates $(\boldsymbol{\Delta})$. Primary producer signals for pelagic phytoplankton and benthic algae are represented by values for particulate organic matter (POM) and giant kelp

Multiple regression models indicated that geographic differences in California sheephead diet composition could be explained by various biological variables (i.e. proxies of prey availability) assessed on community surveys (Table 4 ). We did not detect any significant relationships between $\delta^{13} \mathrm{C}$ and biological covariates. $\delta^{15} \mathrm{~N}$ values were negatively related to sea urchin and crustacean density but positively related to mollusk density (Table 4), suggesting that California sheephead fed at higher trophic levels in locations where sea urchins were rare but mollusks were abundant. PC1 from gut contents varied positively as a function of the percent cover of algae on the benthos (Table 4), so that California sheephead consumed fewer urchins and more gastropods, bryozoans, and barnacles where algal cover was high. PC2 correlated positively with kelp stipe density and negatively with mollusk density (Table 4), indicating that California sheephead consumed fewer urchins and more crabs where kelp was abundant and mollusks were rare. Crabs composed a higher proportion of the diet in locations where sea urchins were rare (Table 4), while urchins were more common in the diet where sea urchin densities were high and kelp stipe densities were low (Table 4). Lastly, the percent of bivalves in the gut contents was positively related to large mollusk densities (Table 4). Overall, these results indicate that prey availability (at least using our proxies) may influence geographic differences in California sheephead diet composition.

\section{Ontogenetic variation in trophic ecology}

Size structures differed significantly among the 9 California sheephead populations (Fig. 6), with larger individuals present at the Northern Channel Islands, San Nicolas, and Santa Barbara Islands than at Santa Catalina and San Clemente Islands and the 2 mainland sites (ANOVA, $F_{8,488}=$ $34.9, \mathrm{p}<0.0001$ ). However, a considerable range of individual sizes was present in each site's collection, allowing us to investigate ontogenetic patterns.

The diets of California sheephead change throughout ontogeny as fish increase in size. Averaged across sampling locations, we found that the $\delta^{13} \mathrm{C}$ signature varied positively as a function of California sheephead size $\left(r^{2}=0.87, p=0.0066\right)$, such that larger individuals concentrated on prey that consume benthic sources of primary production, while smaller individuals focused on prey that rely more on pelagic sources of production (Fig. 7a). The positive relationship between size and $\delta^{13} \mathrm{C}$, however, was not consistent among locations (size $\times$ location interaction term; Table 5); Palos Verdes showed the opposite trend. In contrast, we found that 
Table 3. Comparison of stable isotope values (mean $\pm \mathrm{SD}$ ) of select prey items between the current study and previously published values from other rocky reef sites in southern California. POM: particulate organic matter

\begin{tabular}{|c|c|c|c|c|c|c|}
\hline \multirow[t]{2}{*}{ Taxon } & \multicolumn{2}{|c|}{$\begin{array}{l}\text { Santa Cruz Island } \\
\text { (this study) }\end{array}$} & \multicolumn{2}{|c|}{$\begin{array}{c}\text { San Nicolas Island } \\
\text { (Newsome et al. 2010) }\end{array}$} & \multicolumn{2}{|c|}{$\begin{array}{l}\text { Santa Barbara mainland } \\
\text { (Page et al. 2008) }\end{array}$} \\
\hline & $\delta^{13} \mathrm{C}$ & $\delta^{15} \mathrm{~N}$ & $\delta^{13} \mathrm{C}$ & $\delta^{15} \mathrm{~N}$ & $\delta^{13} \mathrm{C}$ & $\delta^{15} \mathrm{~N}$ \\
\hline Red sea urchin & $-13.8 \pm 1.1$ & $12.1 \pm 0.9$ & $-14.5 \pm 0.6$ & $10.9 \pm 0.7$ & - & - \\
\hline Purple sea urchin & $-12.7 \pm 0.8$ & $11.4 \pm 0.5$ & $-14.2 \pm 0.5$ & $10.3 \pm 0.3$ & $-13.8 \pm 1.3$ & $10.9 \pm 0.5$ \\
\hline Crabs & $-15.3 \pm 0.5$ & $10.9 \pm 0.7$ & $-14.5 \pm 0.8$ & $11.3 \pm 0.9$ & - & - \\
\hline Gastropods & $-14.5 \pm 0.7$ & $11.2 \pm 0.3$ & $-14.3 \pm 0.8$ & $12.8 \pm 0.9$ & $14.2 \pm 0.5$ & $13.7 \pm 0.4$ \\
\hline Giant kelp & $-13.5 \pm 2.2$ & $7.3 \pm 0.5$ & - & - & $-13.2 \pm 1.5$ & $8.9 \pm 1.5$ \\
\hline Barnacles & $-19.8 \pm 0.6$ & $11.7 \pm 0.4$ & - & - & $-17.5 \pm 1.2$ & $10.9 \pm 0.6$ \\
\hline Bryozoan & $-19.3 \pm 1.6$ & $7.5 \pm 0.4$ & - & - & $-18.0 \pm 1.2$ & $12.2 \pm 0.5$ \\
\hline Rock scallop & $-16.8 \pm 0.5$ & $10.4 \pm 0.3$ & $-17.2 \pm 0.86$ & $10.8 \pm 0.26$ & $-15.5 \pm 0.7$ & $11.7 \pm 0.4$ \\
\hline POM & $-20.1 \pm 1.5$ & $5.5 \pm 1.1$ & - & - & $-21.0 \pm 1.2$ & $6.8 \pm 0.8$ \\
\hline
\end{tabular}

$\delta^{15} \mathrm{~N}$ signatures varied negatively as a function of California sheephead size $\left(r^{2}=0.57, p=0.08\right)$, driven by the largest individuals feeding slightly lower on the food chain (Fig. 7b). This relationship was consistent across the 9 sampling locations after controlling for variation among populations (Table 5). We also detected significant ontogenetic changes in multivariate descriptors of the diet. PC1 decreased with increasing size, confirming a greater reliance on mobile invertebrates as California sheephead grow larger (Fig. 7c). However, the relationship was not significant $\left(\mathrm{r}^{2}=\right.$ $0.42, p=0.15$; Fig. 7e), because San Clemente and Santa Catalina showed the opposite trend, with increases in PC1 as a function of size (Table 5). Interestingly, we detected a significant negative relationship with PC2 as a function of size $\left(r^{2}=0.79, p=0.0017\right.$; Fig. 7 d), likely driven by a decreasing emphasis on the consumption of small invertebrates and an increasing reliance on sea urchins as fish grew larger. This pattern was consistent across the 9 sampled populations (Table 5).

The ontogenetic changes in stable isotope signatures may be explained by the strong negative relationship between California sheephead size and the proportion of bivalves found in gut contents $\left(r^{2}=0.95, p=0.001\right.$; Fig. $7 \mathrm{e}$ ) and the contrasting positive relationship between size and the average percentage of the gut volume containing sea urchins $\left(\mathrm{r}^{2}=0.89, \mathrm{p}=0.005\right.$; Fig. 7f). We found significant differences among sites in the percent of gut contents containing bivalves, and the ontogenetic changes were not consistent among sampling locations (Table 5). Fish at Santa Catalina Island increased consumption of bivalves with increasing size; however, this population was dominated by relatively small-bodied individuals (Fig. 6g). Increases in the proportion of sea urchins in the diet with increasing California sheephead size were consistent across the 9 populations sampled (Table 5). We did not detect significant ontogenetic changes in the impor- tance of other common prey items in the diet (e.g. brachyuran crabs, gammarid amphipods, gastropods), either within or among populations.

\section{DISCUSSION}

\section{Causes of geographic variation in trophic ecology}

We found evidence for extensive geographic and ontogenetic variation in the trophic ecology of California sheephead throughout southern California, after sampling distinct populations inhabiting 7 island and 2 mainland locations. A previous study by Cowen (1986) reported differences in California sheephead diets between San Nicolas Island and 3 central Baja California, Mexico, populations. In that study, between-site differences in diets generally reflected prey availability where prey were abundant and California sheephead densities were relatively low (i.e. San Nicolas Island), but not where preferred prey (e.g. crabs) were scarce and California sheephead were abundant (i.e. Cabo Thurloe). In central Baja, diets in locations with dense populations shifted to presumably lowerquality prey items, such as bryozoan-encrusted algae (Cowen 1986). We found that strong geographic differences in trophic ecology occurred on smaller spatial scales among locations within southern California. California sheephead are generalist carnivores and consume over 26 different prey taxa, with the most common prey being crabs, urchins, bivalves, amphipods, shrimp, shelled gastropods, bryozoans, and polychaetes (Fig. 2). While many of the same prey types were consumed at different locations, the proportional importance of particular items to the diet varied among sites. Stable isotope and gut content analyses suggested that sheephead in the Northern Channel Islands and San Nicolas Island consumed more mobile benthic invertebrates (e.g. crabs, urchins, amphipods), 

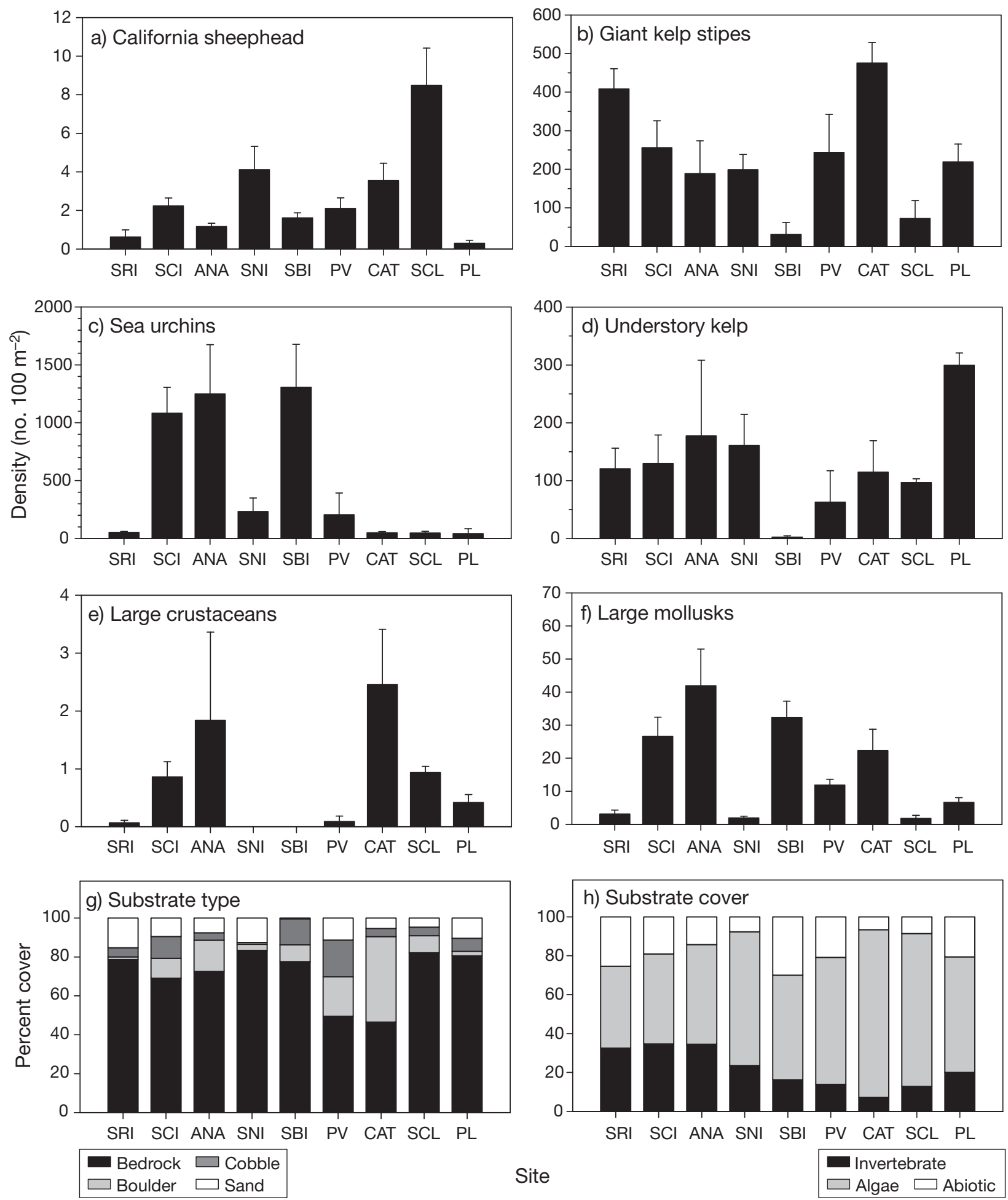

Fig. 5. Abundance of California sheephead, macroalgae, and invertebrates, substrate type, and percent cover characterizing each study location. Densities were enumerated on belt transects and include: (a) California sheephead, (b) giant kelp Macrocystis pyrifera stipes, (c) sea urchins (all species), (d) understory kelp (Cystoseira osmundacea, Eisenia arborea, Laminaria farlowii, Pterygophora californica), (e) large mobile crustaceans (e.g. Panulirus interruptus, Cancer spp.), (f) large mobile mollusks (e.g. Cypraea spadecia, Kelletia kelletii, Megathura crenulata, Megastraea undosum). Shown are numbers per $100 \mathrm{~m}^{2} \pm \mathrm{SE}$. Habitat characteristics from uniform point contact surveys include (g) substrate type and (h) percent cover of sessile organisms. Site abbreviations are listed in Fig. 3 
Table 4. Step-wise multiple regression results examining relationships between diet composition among California sheephead collection locations and biological covariates. Step-wise multiple regression model construction used a threshold significance value of 0.25 for individual factors to enter the model and 0.1 for individual factors to leave. Statistically significant $p$-values are in bold along with the direction of the slope of each term in the model

\begin{tabular}{|c|c|c|c|c|c|}
\hline Factor(s) & Model $r^{2}$ & $\begin{array}{c}\text { Parameter } \\
\text { estimate } \pm \mathrm{SE}\end{array}$ & $t$ & $\mathrm{p} \quad \mathrm{D}$ & $\begin{array}{l}\text { Direction } \\
\text { of slope }\end{array}$ \\
\hline$\delta^{13} \mathrm{C}$ & 0.32 & & & & \\
\hline Invertebrate $\%$ cover & & $5.25 \pm 2.88$ & 1.82 & 0.11 & + \\
\hline$\delta^{15} \mathrm{~N}$ & 0.95 & & & & \\
\hline Kelp stipe density & & $0.00081 \pm 0.00033$ & -2.44 & 0.0927 & - \\
\hline Sea urchin density & & $-0.0011 \pm 0.00023$ & -4.91 & 0.0161 & - \\
\hline Understory kelp density & & $0.00088 \pm 0.00044$ & 1.98 & 0.1417 & + \\
\hline Crustacean density & & $-0.41 \pm 0.072$ & -5.69 & 0.0108 & - \\
\hline Mollusk density & & $0.036 \pm 0.0091$ & 3.98 & 0.0283 & + \\
\hline PC1 gut contents & 0.75 & & & & \\
\hline Algae percent cover & & $4.33 \pm 0.95$ & 4.36 & 0.0026 & + \\
\hline PC2 gut contents & 0.91 & & & & \\
\hline Kelp stipe density & & $0.0042 \pm 0.001458$ & 2.89 & 0.048 & + \\
\hline Sea urchin density & & $0.0015 \pm 0.000834$ & 1.78 & 0.15 & + \\
\hline Mollusk density & & $-0.081 \pm 0.024782$ & -3.26 & 0.031 & - \\
\hline Invertebrate percent cover & & $0.49 \pm 1.745535$ & 0.28 & 0.79 & + \\
\hline$\%$ crab by volume & 0.81 & & & & \\
\hline Sea urchin density & & $-0.014 \pm 0.0048$ & -3.00 & 0.030 & - \\
\hline Algae percent cover & & $-41.14 \pm 30.06$ & -1.37 & 0.30 & - \\
\hline Invertebrate percent cover & & $62.91 \pm 41.48$ & 1.52 & 0.19 & + \\
\hline$\%$ urchins by volume & 0.95 & & & & \\
\hline Sea urchin density & & $0.0066 \pm 0.0022$ & 3.01 & 0.030 & + \\
\hline Kelp stipe density & & $-0.044 \pm 0.0086$ & -5.11 & 0.0037 & - \\
\hline California sheephead densit & sity & $-1.17 \pm 0.46$ & -2.44 & 0.058 & - \\
\hline$\%$ bivalves by volume & 0.74 & & & & \\
\hline Mollusk density & & $0.33 \pm 0.11$ & 3.09 & 0.027 & + \\
\hline Abiotic percent cover & & $25.27 \pm 19.30$ & 1.31 & 0.25 & + \\
\hline Invertebrate percent cover & & $-34.11 \pm 15.78$ & -2.16 & 0.083 & - \\
\hline
\end{tabular}

important by volume; Cowen 1983), while gammarid amphipods occurred irregularly. Unfortunately, we were not able to survey the abundance of all prey items (particularly barnacles and other small inconspicuous invertebrates including amphipods) in the current study, so it is unknown if this change in diet reflects a shift in predator preferences or changes in the abundance of barnacles or gammarid amphipods on the reef. Many of our collections came from the same reef, Dutch Harbor, sampled previously by Cowen. In the 1990s, California sheephead were fished intensely, which led to dramatic reductions in size structure and shifts in life history traits (Hamilton et al. 2007). The population is currently recovering, and it is possible that the process of exploitation and recovery has affected foraging behavior. Alternatively, changes in environmental conditions or species interactions could have altered the abundance of barnacles on these subtidal reefs. Gammarid amphipods are closely associated with both giant kelp and benthic turf algae, and differences in these algal communities could explain the change in this prey taxon between studies.

We detected significant correlations between multivariate descriptions of the diet and life history and demographic parameters measured among populations (Fig. 3). In locations while those in Santa Catalina and San Clemente Islands tended to consume mainly filter feeders (e.g. bivalves, barnacles, bryozoans). California sheephead in populations along the mainland coast were the most general in their diet, consuming relatively equal proportions of a number of common prey classes.

Our collections overlapped with a population sampled by Cowen (1986) almost 30 yr previously at San Nicolas Island. Within sites sampled in different seasons or 1 yr apart, Cowen (1986) reported high percent similarities in diets. Compared to the historical data from San Nicolas Island, we found in the current collections a notable lack of barnacles in the diet and a relatively greater percent volume of gammarid amphipods. In the 1980 collections, barnacles comprised the second most important gut item as calculated by an index of relative importance (fourth most where California sheephead grow rapidly to larger sizes (e.g. Northern Channel Islands and San Nicolas Island), mobile invertebrates such as crabs and sea urchins dominated the diet. In contrast, where California sheephead grow more slowly and attain smaller sizes (e.g. Santa Catalina and San Clemente Islands), the diet composition shifted to alternative prey, such as barnacles, bryozoans, and algae, which may be less nutritious. Similar results were found by Cowen (1986), who reported that diets shifted to these low-quality prey items in central Baja California where California sheephead densities were elevated. In southern California, densities are highest at sites on Santa Catalina and San Clemente Islands, compared to the other populations sampled in the current study. Therefore, dencould restrict growth, and we found that diet composisity-dependent competition for preferred food items 

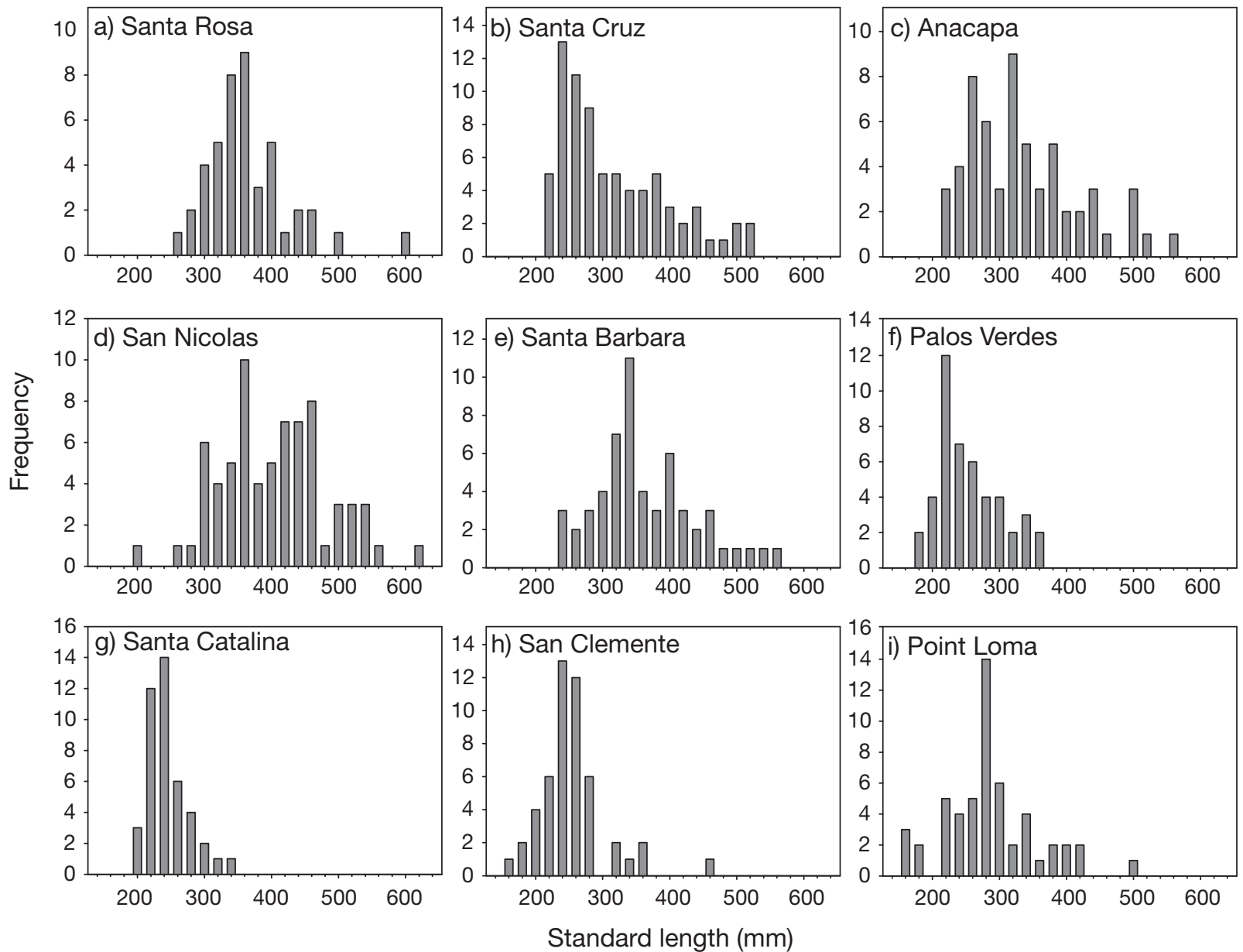

Fig. 6. Semicossyphus pulcher. Size-frequency distributions (standard length in $\mathrm{mm}$ ) of California sheephead from 9 sampling locations

tion (as measured by PC1) shifted from sea urchins and crabs to barnacles, bryozoans, and gastropods as California sheephead density increased. Additionally, northern and western portions of the Southern California Bight are cooler and more productive (increased upwelling and chlorophyll a concentrations; Harms \& Winant 1998), which may influence the standing stock of preferred prey and ultimately enhance growth of California sheephead inhabiting these regions. Populations that consumed a higher proportion of mobile invertebrates also showed increased annual survivorship, matured at larger sizes, exhibited higher reproductive allocation (GSI; index of relative gonad size), and larger energy stores (HSI; index of relative liver size; Fig. 3). Many of these life history and demographic traits are positively correlated with each other, so it is difficult to disentangle the mechanisms by which differences in trophic ecology affect life histories. However, we hypothesize that differences in diet composition directly determine growth rates and energy storage, thereby influencing size-dependent mortality, reproductive output, the timing of life history transitions, and the ability to perform ontogenetic trophic shifts (Werner \& Gilliam 1984). Overall, distinct geographic differences in trophic ecology may have profound effects on fish demography, as well as the composition and structure of prey communities.

The stable isotope data revealed that sites clustered along the carbon axis, such that populations at Santa Catalina, San Clemente, and Santa Barbara Islands were depleted in ${ }^{13} \mathrm{C}$ compared to the Northern Channel Islands, San Nicolas Island, and the mainland populations (Fig. 4a). Based on the gut content results, this appeared to reflect an increased emphasis on consuming sessile filter/suspension feeders in the southern island populations. Stable isotope analyses of common prey items confirmed a distinct shift in $\delta^{13} \mathrm{C}$ between filter feeding organisms and mobile invertebrates. Our comparison of prey isotope values to those from other studies conducted in different locations around southern California indicated that geographic variation in prey isotopic signatures is likely to be less than the 

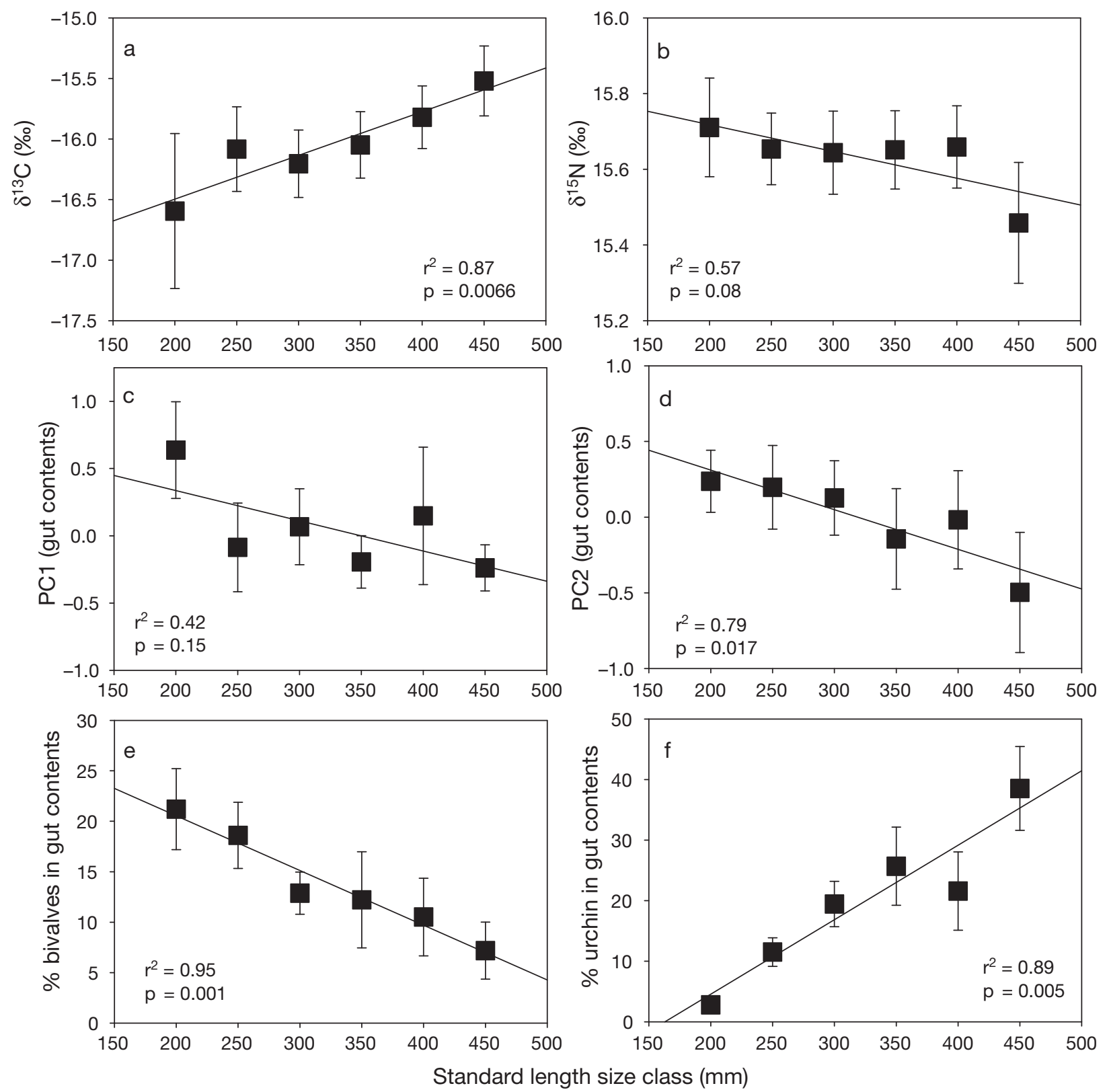

Fig. 7. Semicossyphus pulcher. Ontogenetic variation in the feeding habits of California sheephead. Plots depict relationships between California sheephead size and (a) $\delta^{13} \mathrm{C}$ (i.e. proxy of source of primary production), (b) $\delta^{15} \mathrm{~N}$ (i.e. proxy for trophic level), (c) the first principal component (PC1) from gut contents (-urchins, -crabs, +bryozoans, +barnacles, +gastropods), (e) the second principal component (PC2) from gut contents (-urchins, +crabs), (e) the proportion of gut contents comprised of bivalves, and (f) the proportion of gut contents (by volume) comprised of sea urchins. Shown are mean values ( $\pm 1 \mathrm{SE}$ ) for each $50 \mathrm{~mm}$ size class

large and consistent differences in $\delta^{13} \mathrm{C}$ signatures between filter feeders and benthic-feeding invertebrates. Average levels of $\delta^{13} \mathrm{C}$ across populations were also highly correlated with PC1 from gut contents, which further highlights the agreement between isotopic and gut content data. However, based on the $\delta^{13} \mathrm{C}$ values for the population at Santa Barbara Island, filter feeding bivalves appear to be an important dietary source, while the gut content data point to an appre- ciable consumption of sea urchins (this point is an outlier in Fig. 3f). Our observations at Santa Barbara Island indicate that little kelp has been present since 2005, and reefs surrounding the island are dominated by urchin barrens composed of small purple and red sea urchins (Fig. 5). Sea urchins in barrens often feed little and have small gonads (Harrold \& Reed 1985), and therefore may not provide much nutrition to California sheephead compared to bivalves, despite their 
Table 5. Semicossyphus pulcher. Results of analysis of covariance models examining changes in the trophic ecology of California sheephead as a function of standard length size class (50 mm bins) at 9 locations throughout southern California. Shown are analyses including the factors of size and location with $\delta^{13} \mathrm{C}$ (i.e. proxy of source of primary production), $\delta^{15} \mathrm{~N}$ (i.e. proxy for trophic level), principal component score 1 (PC1) from gut contents, PC2 from gut contents, the proportion of gut contents (by volume) comprised of bivalves, and the proportion of gut contents comprised of sea urchins. Values represent that average per size class per site. Statistically significant $\mathrm{p}$-values are in bold

\begin{tabular}{|lcccc}
\hline Factor & Model $\mathrm{r}^{2}$ & $\mathrm{df}$ & $F$ & $\mathrm{p}$ \\
\hline $\boldsymbol{\delta}^{\mathbf{1 3}} \mathbf{C}$ & 0.91 & & & \\
Size & & 1,45 & 11.2 & $\mathbf{0 . 0 2 3}$ \\
Location & & 8,45 & 23.6 & $\mathbf{< . 0 0 0 1}$ \\
Size $\times$ Location & & 8,45 & 3.6 & $\mathbf{0 . 0 0 5}$ \\
& & & & \\
$\boldsymbol{\delta}^{15} \mathbf{N}$ & 0.76 & & & \\
Size & & 1,45 & 4.5 & $\mathbf{0 . 0 4 3}$ \\
Location & & 8,45 & 7.4 & $<\mathbf{0 . 0 0 0 1}$ \\
Size $\times$ Location & & 8,45 & 1.9 & 0.11 \\
& & & & \\
PC1 (gut contents) & 0.67 & & & \\
Size & & 1,45 & 0.9 & 0.36 \\
Location & & 8,45 & 4.8 & $\mathbf{0 . 0 0 0 9}$ \\
Size $\times$ Location & & 8,45 & 2.5 & $\mathbf{0 . 0 3 6}$ \\
& & & \\
PC2 (gut contents) & 0.84 & & & \\
Size & & 1,45 & 15.7 & $\mathbf{0 . 0 0 0 5}$ \\
Location & & 8,45 & 14.6 & $<\mathbf{0 . 0 0 0 1}$ \\
Size $\times$ Location & & 8,45 & 1.0 & 0.43 \\
& & & & \\
\% bivalves by volume & 0.74 & & & \\
Size & & 1,45 & 6.0 & $\mathbf{0 . 0 2 1}$ \\
Location & & 8,45 & 6.4 & $<\mathbf{0 . 0 0 0 1}$ \\
Size $\times$ Location & & 8,45 & 3.7 & $\mathbf{0 . 0 0 4}$ \\
& & & & \\
\% urchins by volume & 0.60 & & & \\
Size & & 1,45 & 14.5 & $\mathbf{0 . 0 0 0 7}$ \\
Location & & 8,45 & 1.9 & 0.09 \\
Size $\times$ Location & & 8,45 & 0.4 & 0.89 \\
\hline & & & & \\
\hline
\end{tabular}

inclusion in the diet. The integrated stable isotope signature of California sheephead at Santa Barbara Island may either reflect primarily the prey whose tissues are assimilated or the full suite of prey in their gut contents, with shifts in prey isotopic signatures for urchins.

Sea urchins and other prey items (e.g. crabs, gastropods) collected from urchin barren areas at Santa Cruz Island tended be depleted in ${ }^{13} \mathrm{C}(\Delta=-0.78 \pm$ $0.92 \%$ ) compared to the same prey collected from kelp forest habitats (S. L. Hamilton unpubl. data). These baseline shifts in prey isotopic values could explain some of the spatial variation in California sheephead isotope signatures and the discrepancy mentioned previously between stable isotope and gut content data at Santa Barbara Island. However, on average these baseline shifts in prey isotope values appear to be less than the differences observed among sheephead populations (Table 3). Unfortunately, we were only able to collect prey items that corresponded with 1 population on Santa Cruz Island, so further examinations of baseline shifts in prey isotopes at other locations are warranted in the future. In particular, the 2 mainland locations of Palos Verdes and Point Loma exhibited the highest $\delta^{15} \mathrm{~N}$ values in California sheephead tissue of the 9 locations (Fig. 4a), suggestive of feeding at a relatively higher trophic level. However, the gut content data do not fully support that interpretation. Instead, elevated $\delta^{15} \mathrm{~N}$ values at mainland sites may indicate anthropogenic nutrient enrichment from sources such as sewage outfalls, which are known to enhance $\delta^{15} \mathrm{~N}$ values of macroalgae (Dailer et al. 2010) and whole food webs (Hansson et al. 1997). These sources of pollution are more likely to influence waters near population centers on the mainland coast, compared to offshore islands where human population density is low.

\section{Role of California sheephead in kelp forest food webs}

Kelp forests are among the most productive and well-studied ecosystems in the world. Despite decades of research on these dynamic habitats, there is a lack of consensus as to the relative importance of abiotic (e.g. water temperature, storms) versus biotic (e.g. nutrients, grazers, trophic interactions) factors that control kelp abundance (Steneck et al. 2002). In southern California, recent work has questioned the view of a simple trophic cascade with lobsters and California sheephead predators controlling urchin grazers, which in turn control kelp (Foster \& Schiel 2010). While we make no attempt here to partition the importance of these multiple factors, we can hypothesize about the potential effects of California sheephead on southern California rocky reefs given the geographic and ontogenetic patterns in diet that we have documented.

As generalist predators, California sheephead consume different prey in different places, thus their trophic impacts on prey communities are likely to be location specific. For example, Cowen (1986) estimated that at San Nicolas Island (a location of strong upwelling and high productivity), this species consumed $0.06 \%$ of the crab standing stock per day. In contrast, at Cabo Thurloe in Baja California, where densities are higher and crab standing stocks are significantly lower, California sheephead consumed $1.63 \%$ of the available crab per day. In addition, California sheephead were predicted to consume 20 to $33 \%$ of the red sea urchin population annually on San Nicolas Island (Cowen 1983). Experimental removal of California sheephead from an isolated reef in the same study resulted in a $26 \%$ annual increase in red sea 
urchin densities, indicating strong trophic interactions, despite the fact that sea urchins were only the fourth most important prey taxon in the diet (Cowen 1986; see Paine 1969 for a similar effects between Pisaster and Tegula in the intertidal). In addition, Cowen (1983) found that the proportion of exposed sea urchins increased with decreasing California sheephead densities across 5 sites spanning the species' range, indicating the potential for strong indirect trophic effects on grazer behavior. Similarly, Tegner \& Dayton (1981) demonstrated that in the absence of California sheephead and spiny lobsters, purple and red sea urchins in a Point Loma kelp bed exhibited shifts in sizefrequency distributions, occurred at higher densities, and increased the proportion of exposed individuals on the reef. Despite potential issues with these studies pointed out by Foster \& Schiel (2010), it is clear that the predatory impacts of sheephead may vary geographically, and their presumed role as sea urchin predators may only be realized in certain locations, similar to observations of sea otters (Estes et al. 2003, Tinker et al. 2008).

Geographic differences in the importance of sheephead as urchin predators may be related to differences in prey availability among locations, but also due to size-specific predation abilities or preferences. While this study did not measure all aspects of prey availability, we did find that collection locations differed in terms of densities of kelp, sea urchins, crustaceans, and mollusks, and the percent cover of sessile taxa. Geographic differences in diet composition could be explained, to an extent, by these proxies of prey availability, as well as spatial variation in California sheephead densities (Table 4). For example, California sheephead diets contained more sea urchins in locations where sea urchins are abundant and kelp and sheephead densities are relatively low (i.e. urchin barrens). Where sheephead densities are high, diets shifted away from sea urchins and crabs (presumably because these prey are less abundant; $r=-0.59, \mathrm{p}=$ 0.08 ) to alternative prey such as barnacles, gastropods, and bryozoans (PC1 correlated positively with sheephead density; $r=0.74, p=0.024$ ). Cowen (1986) made similar conclusions about shifts in California sheephead diets in relation to how prey availability changes with density-dependent resource competition. Interestingly, where California sheephead are common, benthic percent cover is dominated by algal taxa $(\mathrm{r}=$ $-0.66, p=0.05$ ), potentially because of the removal of preferred invertebrate prey. Taken together, these results and previous studies by Cowen (1983) and Tegner \& Dayton (1981) suggest that California sheephead predation has the potential to influence rocky reef community structure through top-down processes, although further experimental studies are needed to disentangle the complexities of spatial variation in species interactions.

We have shown that the trophic ecology of California sheephead changes throughout ontogeny. Despite differences in size structure among populations (Fig. 6), as California sheephead grow larger in size, gut content and stable isotope data indicated that diets within a location shifted from small sessile filter feeders, like bivalves, to larger mobile invertebrates, such as sea urchins (Fig. 7). In southern California, sea urchin outbreaks are commonly dominated by purple sea urchins Strongylocentrotus purpuratus (Tegner \& Dayton 2000). In examining the urchin spines in the guts of California sheephead, it is evident that they primarily consume the smaller, less defended, and more abundant purple sea urchin than the red sea urchin $S$. franciscanus $(70 \%$ of samples across islands were $S$. purpuratus and $30 \%$ were $S$. franciscanus). It has been argued, based on size-frequency distributions of purple and red sea urchins, that the larger and better defended red sea urchin may attain a partial size refuge from California sheephead predation, while purple sea urchins do not (Tegner \& Dayton 1981).

Our results indicate that only in places where large individuals are present, including, but not limited to, marine protected areas (Froeschke et al. 2006, Tetreault \& Ambrose 2007, Hamilton et al. 2010), will California sheephead have strong trophic impacts on established adult sea urchin populations. California sheephead are fished intensely by commercial and recreational fisheries in southern California (Alonzo et al. 2004), as are red sea urchins. Hamilton et al. (2007) demonstrated that size-selective harvesting of larger sheephead has significantly reduced size structure and altered life history traits at San Nicolas and Santa Catalina Islands, and fishing occurs commonly at the other study sites sampled throughout the region. In light of the size-based changes in the diet that we observed, these results suggest that fishing could potentially, albeit indirectly, affect kelp abundance by removing the large fish that are capable of handling and successfully preying on sea urchins. A recent study in Tasmania showed that kelp forest resilience was enhanced inside marine reserves because only in protected areas did lobsters reach large enough sizes to prey upon an invasive sea urchin species, which was responsible for widespread kelp loss outside reserves where lobsters are overfished (Ling et al. 2009). While neither the current study nor Ling et al. (2009) investigated the myriad other forcing factors that have been shown to influence kelp dynamics, we argue that restoration of the size structure of California sheephead in southern California through fisheries management actions has the potential to influence kelp forest ecosystems in the future. 
Acknowledgements. We thank K. Davis, P. Carlson, A. Parsons-Field, J. Barr, G. McMichael, A. Ray, L. Bellquist, S. Sandin, O. Sosa-Nishizaki, N. Shears, A. Salomon, K. Anthony, C. Mireles, B. Rogers, H. Zemel, C. Mull, S. Trbovich, C. Martin, A. Floyd, T. Farrugia, M. Espinoza, M. Donovan, and C. Aime for help with field collections and fish dissections. A. Salomon and M. Page graciously supplied stable isotope data for prey taxa and POM. We thank T. Anderson, M. Edwards, and other participants involved in the Bight '08 surveys for community data. This manuscript was greatly improved by A. Salomon and 3 anonymous reviewers. Funding was generously provided by NOAA (grant no. NA04OAR4170038) and the California Sea Grant College Program (project no. R/OPCFISH05) through NOAA's National Sea Grant College Program, US Dept. of Commerce, and was supported in part by the Ocean Protection Council. Additional financial support was provided by the Channel Islands National Marine Sanctuary and the Partnership for Interdisciplinary Studies of Coastal Oceans, which is funded by the David and Lucille Packard Foundation and the Gordon and Betty Moore Foundation. This is PISCO publication no. 373 .

\section{LITERATURE CITED}

Alonzo SH, Key M, Ish T, MacCall A (2004) Status of the California sheephead (Semicossyphus pulcher) stock (2004). California Department of Fish and Game. Available at www.dfg.ca.gov/mrd/sheephead2004/index.html

Beverton RJH, Holt SJ (1957) On the dynamics of exploited fish populations. Fish Invest Ser II 19:1-533

Buckel JA, Lectcher BH, Connover DO (1998) Effects of a delayed onset of piscivory on the size of age-0 bluefish. Trans Am Fish Soc 127:576-587

Caselle JE, Hamilton SL, Schroeder DM, Love MS, Standish JD, Rosales-Casian JA, Sosa-Nishizaki O (2011) Geographic variation in density, demography, and life history traits of a harvested temperate sex-changing reef fish. Can J Fish Aquat Sci 68:288-303

> Cowen RK (1983) The effect of sheephead (Semicossyphus pulcher) predation on red sea urchin (Strongylocentrotus franciscanus) populations: an experimental analysis. Oecologia 58:249-255

Cowen RK (1985) Large scale pattern of recruitment by the labrid, Semicossyphus pulcher: causes and implications. J Mar Res 43:719-742

Cowen RK (1986) Site-specific differences in the feeding ecology of the California sheephead, Semicossyphus pulcher (Labridae). Environ Biol Fishes 16:193-203

Cowen RK (1990) Sex change and life history patterns of the labrid Semicossyphus pulcher, across an environmental gradient. Copeia 1990:787-795

Dailer ML, Knox RS, Smith JE, Napier M, Smith CM (2010) Using $\delta^{15} \mathrm{~N}$ values in algal tissue to map locations and potential sources of anthropogenic nutrient inputs on the island of Maui, Hawaii, USA. Mar Pollut Bull 60:655-671

Estes JA, Riedman ML, Staedler MM, Tinker T, Lyon BE (2003) Individual variation in prey selection by sea otters: patterns, causes and implications. J Anim Ecol 72:144-155

Foster MS, Schiel DR (2010) Loss of predators and the collapse of southern California kelp forests (?): alternatives, explanations and generalizations. J Exp Mar Biol Ecol 393:59-70

Foy RJ, Norcross BL (1999) Spatial and temporal variability in the diet of juvenile Pacific herring (Clupea pallasi) in Prince William Sound, Alaska. Can J Fish Aquat Sci 77: 697-706
Froeschke JT, Allen LG, Pondella DJ (2006) The fish assemblages inside and outside of a temperate marine reserve in southern California. Bull South Calif Acad Sci 105: 126-142

Graham MH (2004) Effects of local deforestation on the diversity and structure of southern California giant kelp forest food webs. Ecosystems 7:341-357

Hamilton SL, Caselle JE, Standish JD, Schroeder DM, Love MS, Rosales-Casian JA, Sosa-Nishizaki O (2007) Sizeselective harvesting alters life histories of a temperate sexchanging fish. Ecol Appl 17:2268-2280

- Hamilton SL, Caselle JE, Malone D, Carr MH (2010) Incorporating biogeography into evaluations of the Channel Islands marine reserve network. Proc Natl Acad Sci USA 107:18272-18277

> Hansson S, Hobbie JE, Elmgren R, Larsson U, Fry B, Johansson $S$ (1997) The stable nitrogen isotope ratio as a marker of food-web interactions and fish migration. Ecology 78:2249-2257

> Harms S, Winant CD (1998) Characteristic patterns of circulation in the Santa Barbara Channel. J Geophys Res 103: 3041-3065

> Harrold C, Reed DC (1985) Food availability, sea urchin grazing, and kelp forest community structure. Ecology 66: 1160-1169

Hesslein RH, Hallard KA, Ramlal P (1993) Replacement of sulfur, carbon, and nitrogen, in tissue of growing broad whitefish (Coregonus nasus) in response to a change in diet traced by $\delta^{34} \mathrm{~S}, \delta^{13} \mathrm{C}$, and $\delta^{15} \mathrm{~N}$. Can J Fish Aquat Sci 50:2071-2076

> Kelly JF (2000) Stable isotopes of carbon and nitrogen in the study of avian and mammalian trophic ecology. Can J Zool 78:1-27

> Lambert Y, Dutil JD (1997) Condition and energy reserves of Atlantic cod (Gadus morhua) during the collapse of the northern Gulf of St. Lawrence stock. Can J Fish Aquat Sci 54:2388-2400

Ling SD, Johnson CR, Frusher SD, Ridgway KR (2009) Overfishing reduces resilience of kelp beds to climate-driven catastrophic phase shift. Proc Natl Acad Sci USA 106: 22341-22345

McCormick MI (2003) Consumption of coral propagules after mass spawning enhances larval quality of damselfish through maternal effects. Oecologia 136:37-45

Menge BA, Berlow EL, Blanchette CA, Navarrete SA, Yamada SB (1994) The keystone species concept: variation in interaction strength in a rocky intertidal habitat. Ecol Monogr 64:249-286

Minagawa M, Wada E (1984) Stepwise enrichment of $\delta^{15} \mathrm{~N}$ along food chains: further evidence and the relation between $\delta^{15} \mathrm{~N}$ and animal age. Geochim Cosmochim Acta 48:1135-1140

Newsome SD, Bentall GB, Tinker MT, Oftedal OT, Ralls K, Estes JA (2010) Variation in $\delta^{13} \mathrm{C}$ and $\delta^{15} \mathrm{~N}$ diet-vibrissae trophic discrimination factors in a wild population of California sea otters. Ecol Appl 20:1744-1752

> Olson MH (1996) Ontogenetic niche shifts in largemouth bass: variability and consequences for first-year growth. Ecology 77:179-190

Page HM, Reed DC, Brzezinski MA, Melack JM, Dugan JE (2008) Assessing the importance of land and marine sources of organic matter to kelp forest food webs. Mar Ecol Prog Ser 360:47-62

> Paine RT (1969) The Pisaster-Tegula interaction: prey patches, predator food preference, and intertidal community structure. Ecology 50:950-961

Post DM (2002) Using stable isotopes to estimate trophic posi- 
tion: models, methods, and assumptions. Ecology 83: 703-718

Power ME (1992) Top-down and bottom-up forces in food webs: Do plants have primacy? Ecology 73:733-746

Ricker WE (1975) Computation and interpretation of biological statistics of fish populations. Bull Fish Res Board Can 191:1-382

Robertson DR, Ackerman JL, Choat JH, Posada JM, Pitt J (2005) Ocean surgeonfish Acathurus bahianus. I. The geography of demography. Mar Ecol Prog Ser 295:229-244

Rosales-Casian JA, Gonzalez-Camaho JR (2003) Abundance and importance of fish species from the artisanal fishery on the Pacific Coast of northern Baja California. Bull South Calif Acad Sci 102:51-65

Sanford E, Worth DJ (2009) Genetic differences among populations of a marine snail drive geographic variation in predation. Ecology 90:3108-3118

Scharf FS, Juanes F, Rountree RA (2000) Predator size-prey size relationships of marine fish predators: interspecific variation and effects of ontogeny and body size on trophicniche breadth. Mar Ecol Prog Ser 208:229-248

Siddon CE, Witman JD (2004) Behavioral indirect interactions: multiple predator effects and prey switching in the rocky subtidal. Ecology 85:2938-2945

Steneck RS, Graham MH, Bourque BJ, Corbett D, Erlandson JM, Estes JA, Tegner MJ (2002) Kelp forest ecosystems: biodiversity, stability, resilience, and future. Environ Conserv 29:436-459

Sundberg MA, Loke KA, Lowe CG, Young KA (2009) Gonadal restructuring during sex transition in California sheephead: a reclassification three decades after initial studies. Bull South Calif Acad Sci 108:16-28

Editorial responsibility: John Choat,

Townsville, Queensland, Australia
Sutton TM, Ney JJ (2001) Size-dependent mechanisms influencing first-year growth and winter survival of stocked striped bass in a Virginia mainstream reservoir. Trans Am Fish Soc 130:1-17

Tegner MJ, Dayton PK (1981) Population structure, recruitment, and mortality of two sea urchins (Strongylocentrotus franciscanus and $S$. purpuratus) in a kelp forest. Mar Ecol Prog Ser 5:255-268

Tegner MJ, Dayton PK (2000) Ecosystem effects of fishing in kelp forest communities. ICES J Mar Sci 57:579-589

Tetreault I, Ambrose RF (2007) Temperate marine reserves enhance targeted but not untargeted fishes in multiple notake MPAs. Ecol Appl 17:2251-2267

Tinker MT, Bentall G, Estes JA (2008) Food limitation leads to behavioral diversification and dietary specialization in sea otters. Proc Natl Acad Sci USA 105:560-565

Topping DT, Lowe CG, Caselle JE (2006) Site fidelity and seasonal movement patterns of adult California sheephead Semicossyphus pulcher (Labridae): an acoustic monitoring study. Mar Ecol Prog Ser 326:257-267

> Wainright SC, Fuller CM, Michener RH, Richards RA (1996) Spatial variation of trophic position and growth rate of juvenile striped bass (Morone saxatilis) in the Delaware River. Can J Fish Aquat Sci 53:685-692

Warner RR (1975) The reproductive biology of the protogynous hermaphrodite Pimelometopon pulchrum (Pisces: Labridae). Fish Bull 73:262-283

- Werner EE, Gilliam JF (1984) The ontogenetic niche and species interactions in size-structure populations. Annu Rev Ecol Syst 15:393-425

Werner EE, Mittelbach GG (1981) Optimal foraging: field tests of diet choice and habitat switching. Am Zool 21: 819-829

Submitted: July 30, 2010; Accepted: February 14, 2011

Proofs received from author(s): April 28, 2011 